Chirurgia (2021) 116: 657-663

No. 6, November - December

Copyright@ Celsius

http://dx.doi.org/10.21614/chirurgia.116.6.657

\title{
Emergency Surgery for Small Bowel Hemangioma. A review of the literature
}

\author{
Florin Iordache ${ }^{1,2 \star}$, Claudiu Turculeț ${ }^{1,2}$, Mircea Beurann ${ }^{1,2}$, Dragos Ene $^{1,2}$, Bogdan Gaspar ${ }^{1,2}$, Florin Georgescu ${ }^{1,2}$, \\ Cristina Niculae', Tiberiu Giumba' ${ }^{1}$, Cătălin Bărăian' ${ }^{1}$
}

1Department of Surgery, Emergency Hospital, Bucharest, Romania

'University of Medicine and Pharmacy "Carol Davila“, Bucharest, Romania

${ }^{*}$ Corresponding author:

Florin lordache, MD

Department of Surgery

Emergency Hospital, Bucharest

C. Floreasca 8, District 1, Bucharest, Romania, P0 014461

E-mail: florin_iordache@yahoo.com

\section{Rezumat}

Interventiile chirurgicale de urgență în hemangioamele intestinale. Un review al literaturii

Introducere: Hemangioamele intestinului subtire sunt tumori rar întâlnite în practică. Pacienții se prezintă de obicei în urgență cu anemie, sângerare gastro-intestinală sau dureri abdominale. Scopul acestei revizuiri a literaturii de specialitate este de a evalua modalitățile de diagnosticare, opțiunile terapeutice şi rezultatele acestora în cazul hemangioamelor intestinale.

Metodă: Acest studiu reprezintă o trecere în revistă a literaturii recente analizând pacienții cu hemangiom intestinal cu sângerare în ultimii cinci ani, incluzând şi un caz internat în instituția noastră. Criteriile de căutare au fost definite folosind termenii MeSH. Analiza descriptivă a fost efectuată în consecință.

Rezultate: În ultimii cinci ani am găsit în total 24 de cazuri, al nostru fiind al 25-lea. Evaluarea literaturii de specialitate a demonstrat că diagnosticul este rar stabilit preoperator (numai în $28 \%$ dintre cazuri). Mai mult de jumătate din tumori au fost localizate în ileon. Chirurgia rămâne principala opțiune terapeutică (în 88\% din cazuri). Tratamentul non-chirurgical (endoscopic şi/sau radiologic) are succes într-un mic număr de cazuri, în special în cazul tumorilor mici.

Concluzii: Chirurgia este principala opțiune terapeutică în cazul hemangioamelor mari, în timp ce pentru tumorile de dimensiuni mici sunt utile metodele de tratament non-chirurgicale.

Cuvinte cheie: hemangiom, hemoragie, chirurgie, intestin subțire 


\section{Abstract}

Background: Hemangiomas of the small intestine are tumors rarely found in practice. Patients usually present in emergency settings with anemia, gastrointestinal bleeding or abdominal pain. The purpose of this review of the literature is to evaluate the diagnostic modalities, therapeutic options and their results in cases of intestinal hemangiomas.

Methods:This is a review of the recent literature concerning intestinal hemangioma with bleeding in the last five years including one case from our institution. Search criteria were defined using $\mathrm{MeSH}$ terms. The descriptive analysis was performed accordingly.

Results: In the last five years there was a total of 24 cases ours being the $25^{\text {th }}$ with a predominance of male patients ( 20 cases). Literature search found a low threshold for preoperative diagnostic (only in $28 \%$ of the cases). More than half of the tumors were in the ileum. Surgery is the main therapeutic option (in $88 \%$ of the cases). Nonsurgical treatment (endoscopic or radiological) can rarely be employed successfully.

Conclusions: Surgery is the main treatment for larger hemangiomas while for smaller ones nonsurgical treatment methods are available.

Key words: hemangioma, bleeding, surgery, small bowel

\section{Introduction}

Gastrointestinal (GI) bleeding is one of the most unpredictable emergencies encountered in medical practice. Hemorrhage from the oesophagus to duodenum is defined as upper gastro-intestinal bleeding (UGIB) while lower gastro-intestinal hemorrhage has its origin from the colon to anorectum. Obscure bleeding, defined as hemorrhage without identification of the source, represents $10 \%$ of total GI bleeding (1). Small bowel bleeding is rare but is the commonest cause of obscure GI bleed (OGIB). Approximately 5-10\% of GI bleeding occurs from the small bowel, defined as the region between the ampulla of Vater and the ileocecal valve $(2,3)$. However, the small bowel is responsible for $45 \%-75 \%$ of all OGIB cases. The etiology of small bowel bleedings is dominated by vascular abnormalities (angio-dysplasia, telangiectasia) which account for $70-80 \%$ of the cases, followed by small intestine tumors that account for $5-10 \%$ (2). The peak age of the onset of small intestinal tumors is about 50 years and account for only $1-2 \%$ of all gastrointestinal tumors (2).

Hemangioma is a rare type of tumor responsible for small bowel bleeding.
Moreover, the diagnostic in these cases is difficult, especially in emergency. We report a case of a serious bleeding from a ruptured small bowel hemangioma with hemoperitoneum. We have, also, reviewed the recent literature, mainly focusing on the diagnosis and therapeutic options for this rare tumor.

\section{Method and Material}

\section{Search Criteria}

Beginning from 2016 a search of the literature according to PRISMA guidelines was performed using the following search terms: Hemorrhage OR bleeding OR "acute anemia" OR "blood loss" OR "Hemorrhage" [MeSH] OR "Blood Loss, Surgical" [MeSH]; "Small intestine*" OR "Small Bowel*" OR: "Intestine, Small" [MeSH]; Hemangioma* OR "Vascular Tumor*" OR "Vascular Neoplasm*" OR "Blood Vessel* Tumor*" OR " Blood Vessel* Neoplasm*" OR "Hemangioma" [ MeSH] OR "Hemangioma, Cavernous" [MeSH] OR "Hemangioma, Capillary" [MeSH] OR ("Neoplasms, Vascular Tissue" [Mesh]) OR "Vascular Neoplasms" [MeSH] (see the flowchart in Fig. 1) (4). The language was limited too English. 


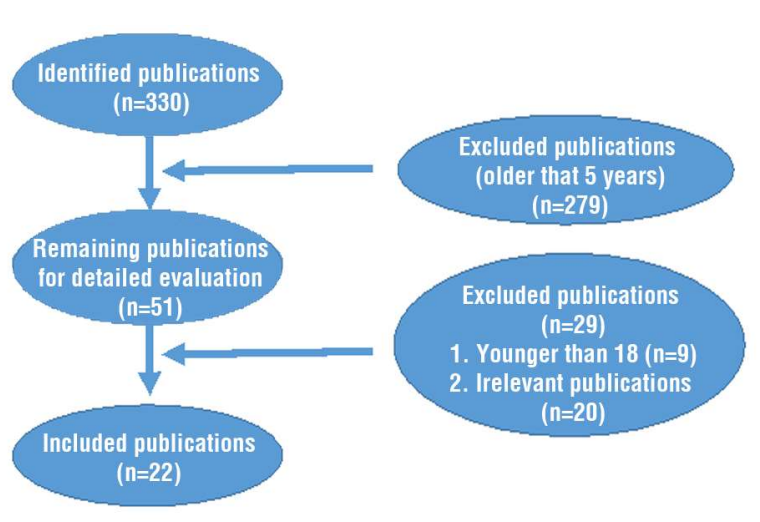

Figure 1. Database flow-chart

\section{Data Collection}

Both abstracts and full text articles, where available, were reviewed. Data, regarding the clinical features, type of tumor, treatment were extracted.

\section{Definitions}

A hemangioma is a benign tumor formed of capillary-like blood vessels of small or large caliber. It has thin-walled blood-filled vessels lined by a single layer of endothelial cells. There are capillary and cavernous hemangiomas. Cavernous hemangioma has large cystically dilated vessels with thin walls; intravascular thrombosis or calcification is common.

A hemangiolymphangioma is a mixed benign tumor formed by proliferation of varied vessel types (lymphatics, capillaries, veins); almost all were in both the submucosa and the mucosa (5).

Acute bleeding is defined as overt GI bleeding visible in the form of hematemesis, melena, or hematochezia that was new in onset (presenting within $72 \mathrm{~h}$ of inciting bleed). Hematochezia from a lesion below the ampulla of Vater to the terminal ileum is defined as mid-GI bleeding. Obscure gastrointestinal bleeding (OGIB) is defined as occult or overt bleeding of unknown origin that persists or recurs after an initial negative endoscopic evaluation, including esogastroduodenoscopy (EGD) and colonoscopy (3).

\section{Results}

Our search yielded 330 titles from which 279 were excluded. Of the remaining 51 articles after reviewing only 22 remained (Fig. I).

For hemangiomatous tumors of the small bowel due to their rarity our search yielded only case reports. In the last five years beginning from 2016 we have found a total of 24 cases our being the $25^{\text {th }}$. The types of hemangiomas, the presentation, the diagnostic techniques employed, the necessity of blood transfusion are presented in the Table 1. In Table 2 we have shown the type of surgical intervention performed, the topography, the macroscopic and pathological types of tumors, and the nonsurgical therapies employed. The results showed a predominance of male patients (20 cases) and only 5 women. The median age of the pooled cases was 53 years (range 27-85 years). Most of the cases presented for acute or chronic microcytic anemia and, the majority had melena or hematochezia. After the introduction of capsule endoscopy (CE) and balloon-assisted enteroscopy (BAE), preoperative diagnosis of hemangioma and hemangioma-like tumors has improved. Capsule endoscopy and balloon-assisted enteroscopy were the most frequent employed methods of diagnostic followed by contrastenhanced computed tomography. Nevertheless, we have found that the preoperative diagnostic was found in only 7 of the 25 cases we have collected. The location of the tumor(s) was in the jejunum in 14 cases, ileum in 8 cases, both jejunum and ileum in 2 cases and, in one patient hemangiomas were found in the duodenum, jejunum. Macroscopic appearance in 11 cases the aspect was polypoid, and a submucosal tumor was found in 6 cases. No available description was found for the rest of the cases. Pathological examination demonstrated cavernous hemangioma in 12 cases (including ours), capillary hemangioma in 6 cases, hemangiolymphangioma in 3 cases, and in one case hemangioendothelioma. In the other 3 cases no specific data were available.

Nonsurgical treatment was successfully employed only 3 cases and unsuccessful in one 
Table 1. Characteristics of the patients with bleeding hemangioma of the small bowel

\begin{tabular}{|c|c|c|c|c|c|c|c|}
\hline Author & Year & Age $(Y)$ & Sex & Presentation & $\begin{array}{c}\text { Admission } \\
\text { Hemoglobin } \\
\text { (g/dl) }\end{array}$ & $\begin{array}{l}\text { Blood } \\
\text { transfusion }\end{array}$ & Diagnostic tool \\
\hline Belvis Jimınez M et al (8) & 2017 & 77 & $M$ & Chronic anemia & NA & Yes & CE, BAE \\
\hline$\overline{Z \text { Zhang GY et al (9) }}$ & 2017 & 44 & $M$ & Fatigue, dizziness,melena & 4,1 & Yes & $\mathrm{CE}$ \\
\hline Aoyama T et al (10) & 2020 & 58 & $\mathrm{~F}$ & Hematochezia & 16 & No & CECT, CE, BAE \\
\hline Al-Tkrit A et al (11) & 2020 & 32 & $M$ & Syncope, dizziness & 12,7 & Yes & Colonoscopy, CE \\
\hline Xiao NJ et al. (12) & 2020 & 42 & $M$ & Melena, dizziness, fatigue & 5,3 & Yes & $\mathrm{CE}, \mathrm{BAE}$ \\
\hline Moein Jahromi B et al (13) & 2018 & 75 & $\mathrm{~F}$ & Chronic anemia & NA & $\overline{N A}$ & $\mathrm{CA}, \mathrm{PE}$ \\
\hline Takase $\mathrm{N}$ et al (14) & 2017 & 62 & $\mathrm{~F}$ & Fatigue, melena & 3,8 & Yes & $\mathrm{CE}, \mathrm{BAE}$ \\
\hline Takase $\mathrm{N}$ et al (14) & 2017 & 52 & $M$ & Melena & 11,3 & No & CECT, CE, BAE \\
\hline Kano T et al (15) & 2021 & 29 & $\bar{M}$ & Chronic diarrhea & 16,3 & No & CECT, CE, BAE \\
\hline Silva JC et al. (16) & 2020 & 85 & M & Melena & 7,6 & NA & $\begin{array}{l}\text { Colonoscopy, CE, } \\
\text { BAE }\end{array}$ \\
\hline Ikeoka S et al (17) & 2020 & 84 & $M$ & Fatigue, melena, chronic anemia & 6,4 & Yes & $\mathrm{CE}, \mathrm{BAE}$ \\
\hline Heo TG (18) & 2021 & 38 & M & Melena & Normal & No & CECT \\
\hline Grgić D et al (19) & 2019 & 73 & M & Chronic anemia & Mild Anemia & NA & CT, CE, BAE \\
\hline Grgić D et al (19) & 2019 & 63 & M & Chronic anemia, fatigue, weakness & NA & NA & $\mathrm{CE}$ \\
\hline Duanmu J et al (20) & 2021 & 50 & $M$ & Hematochezia & 5,2 & Yes & $\begin{array}{l}\text { CT, } \\
\text { Esophagogastroduodenoscopy }\end{array}$ \\
\hline Durer C et al (21) & 2018 & 66 & M & Leg pain & 5,4 & Yes & $\mathrm{CE}, \mathrm{BAE}$ \\
\hline Dayan D et al (22) & 2019 & 53 & $\mathrm{M}$ & Weakness, dizziness, muscle cramps & 5 & Yes & CE, CT \\
\hline Zhang D et al (23) & 2019 & 67 & $M$ & Follow-up colonoscopy of Crohn's disease & 12,9 & No & Colonoscopy \\
\hline Ejtehadi F et al (24) & 2017 & 40 & $M$ & Fatigue, palpitations & 9,9 & NA & $\begin{array}{l}\text { Red blood cell scintigraphy, } \\
\text { CT enterography }\end{array}$ \\
\hline Wang B et al (24) & 2018 & 73 & M & Light headedness, melena, weight loss & NA & NA & CE, BAE \\
\hline Majethia HV et al (25) & 2021 & 45 & $\mathrm{~F}$ & Vomiting, abdominal pain, weight loss & 12,5 & No & CECT \\
\hline Iwaya $Y$ et al (26) & 2018 & 70 & $\mathrm{M}$ & Chronic anemia, melena & NA & NA & CE, BAE \\
\hline Wang Y. et al (27) & 2018 & 27 & $\mathrm{M}$ & Melena and dizziness & 6,6 & $\overline{N A}$ & CE, BAE \\
\hline $\begin{array}{l}\text { Yang SX (28) } \\
\text { n }\end{array}$ & 2021 & 37 & $\mathrm{~F}$ & Melena & 4,3 & Yes & Colonoscopy, CE, BAE \\
\hline Our case & 2021 & 27 & M & Loss of consciousness, melena & 8 & Yes & CECT \\
\hline
\end{tabular}

CE-capsule endoscopy, BAE - balloon assisted enteroscopy, CT - computed tomography, CECT - contrast enhanced CT-scan

Table 2. Characteristics of the patients with bleeding small bowel hemangioma, topography, and type of treatment

\begin{tabular}{|c|c|c|c|c|c|c|}
\hline Author & $\begin{array}{l}\text { Preoperative } \\
\text { diagnostic }\end{array}$ & $\begin{array}{l}\text { Hemangioma } \\
\text { location }\end{array}$ & $\begin{array}{l}\text { Hemangioma } \\
\text { size }(\mathrm{mm})\end{array}$ & $\begin{array}{l}\text { Hemangioma } \\
\text { form }\end{array}$ & Treatment & Pathological examination \\
\hline Belvis Jimınez $\mathrm{M}$ et al & No & Jejunum & 25 & Polypoid tumor & Surgical resection & Capillary hemangioma \\
\hline Zhang GY et al & No & Jejunum & NA & Polypoid tumor & Surgical resection & Cavernous hemangioma \\
\hline Aoyama T et al & No surgery & $\begin{array}{c}\text { Duodenum, } \\
\text { Jejunum, lleum }\end{array}$ & $10-20$ & Submucosal tumors & Sclerotherapy & Hemangioma \\
\hline Al-Tkrit $A$ et al & No & Jejunum & NA & NA & $\begin{array}{l}\text { SMA Arteriography } \\
\text { with Embolisation } \\
\text { Laparoscopic resection }\end{array}$ & Cavernous hemangioma \\
\hline$\overline{\text { Xiao NJ et al. }}$ & No & Jejunum & NA & Lobulate tumor & Sclerotherapy & Hemangiolymphangioma \\
\hline Moein Jahromi B et al & No & Jejunum & 24 & Polypoid tumor & Laparoscopic resection & Capillary hemangioma \\
\hline Takase $\mathrm{N}$ et al & Yes & Jejunum & 15 & Polypoid tumor & Laparoscopic assited resection & Cavernous hemangioma \\
\hline Takase $\mathrm{N}$ et al & Yes & Ileum & 10 & Submucosal tumor & Laparoscopic assited resection & Capillary hemangioma \\
\hline Kano T et al & Yes & Ileum & 150 & Submucosal tumors & Laparoscopic assited resection & Cavernous hemangioma \\
\hline Silva JC et al. & No surgery & Jejunum, lleum & NA & Polypoid tumors & Supportive treatment & Hemangiomas \\
\hline Ikeoka S et al & No & Jejunum & 7 & Polypoid tumor & Endoscopic mucosal resection & Capillary hemangioma \\
\hline Heo TG & No & Jejunum & 10 & NA & Laparoscopic resection & Cavernous hemangioma \\
\hline Grgić D et al & No & Ileum & 20 & Submucosal tumor & Surgical resection & Hemangioma \\
\hline Grgić D et al & No & Jejunum & 80 & Polypoid tumor & Surgical resection & Hemangioma \\
\hline Duanmu J et al & Yes & Duodenum & NA & Submucosal tumor & Surgical resection & Cavernous hemangioma \\
\hline Durer $\mathrm{C}$ et al & No & Jejunum & 25 & Submucosal tumor & Surgical resection & Cavernous hemangioma \\
\hline Dayan D et al & No & Jejunum & 250 & NA & Surgical resection & Cavernous hemangioma \\
\hline Zhang D et al & No surgery & lleum & 8 & Pedunculated polyp & Polypectomy & Capillary hemangioma \\
\hline Ejtehadi $\mathrm{F}$ et al & No & Jejunum & NA & NA & Surgical resection & Cavernous hemangioma \\
\hline Wang B et al & No & Ileum & 20 & Polypoid tumor & Laparoscopic resection & Capillary hemangioma \\
\hline Majethia HV et al & No & Ileum & NA & NA & Laparoscopic assited resection & Cavernous hemangioma \\
\hline Iwaya Y et al & No & Jejunum & 20 & Polypoid tumor & Laparoscopic resection & Hemangiolymphangioma \\
\hline Wang Y. et al & No & Jejunum & 7 & NA & Surgical resection & Hemangioendothelioma \\
\hline Yang SX & No & lleum & 65 & NA & Laparoscopic assited resection & Haemolymphangioma \\
\hline Present case & No & lleum & 50 & Submucosal tumor & Surgical resection & $\begin{array}{c}\text { Cavernous and capillary } \\
\text { hemangioma }\end{array}$ \\
\hline
\end{tabular}


(Table 2). The main therapeutic option was surgery and the most frequently performed surgical procedure was resection (10 open procedures and 12 laparoscopically - Table 2). No deaths were reported.

\section{Clinical Case}

A 27-year-old male patient was brought to our ER by ambulance after a same level fall due to loss of consciousness. His past medical history included hypertension in treatment and chronic alcohol consumption. At admittance the patient displayed psychomotor agitation, skin pallor, blood pressure of $164 / 84 \mathrm{mmHg}$ with a pulse of $70 \mathrm{bpm}$, abdominal distension, hypogastric tenderness, and melena. Routine blood tests found a moderate microcytic hypochromic anemia $(\mathrm{Hb}$ was $8 \mathrm{~g} / \mathrm{dl}, \mathrm{MCV}=$ $79,9 \mathrm{fL}, \mathrm{MCH}=25,5 \mathrm{pg}$ ) and slightly elevated liver enzymes and lipase. Resuscitation with crystalloid and blood products was initiated. An emergency contrast enhanced computed tomography (CECT) was performed. The CTscan revealed major hemoperitoneum, fatty liver, and two possible splenic lacerations one in the anterosuperior half and another one posteriorly (Figs. 2, 3). No evidence of active bleeding ("blush") was demonstrated. Due to the unclear circumstances of the fall and the presence of a major hemoperitoneum the patient was taken immediately to the operating room for an exploratory laparotomy. Through median laparotomy the presence of the hemoperitoneum was asserted $(2 \mathrm{~L}$ of blood and clots) but no injury of the spleen was encountered. Instead, the spleen was found to be segmented explaining the CT-scan interpretation. The bleeding source was a small bowel tumor located at about $20 \mathrm{~cm}$ from the ileocecal valve (Fig. A). No enlarged lymph-nodes were found. A segmentary ileal resection was performed (about $20 \mathrm{~cm}$ ) with a primary end-to-end hand-sewn anastomosis with 4-0 PDO. The pathological examination of the resected bowel showed a ruptured mixed capillary and cavernous hemangioma (Fig. 5).

In the first postoperative day the status of

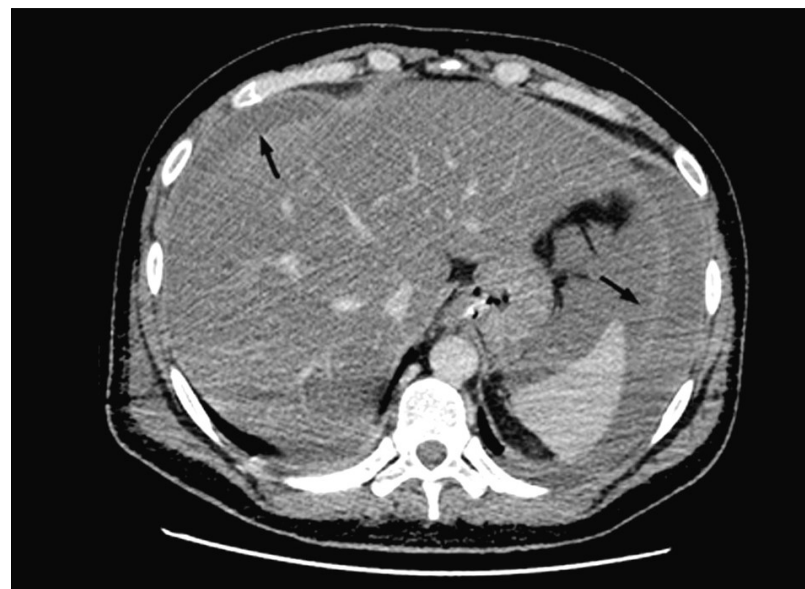

Figure 2. Large hemoperitoneum seen peri splenic and perihepatic (arrows)

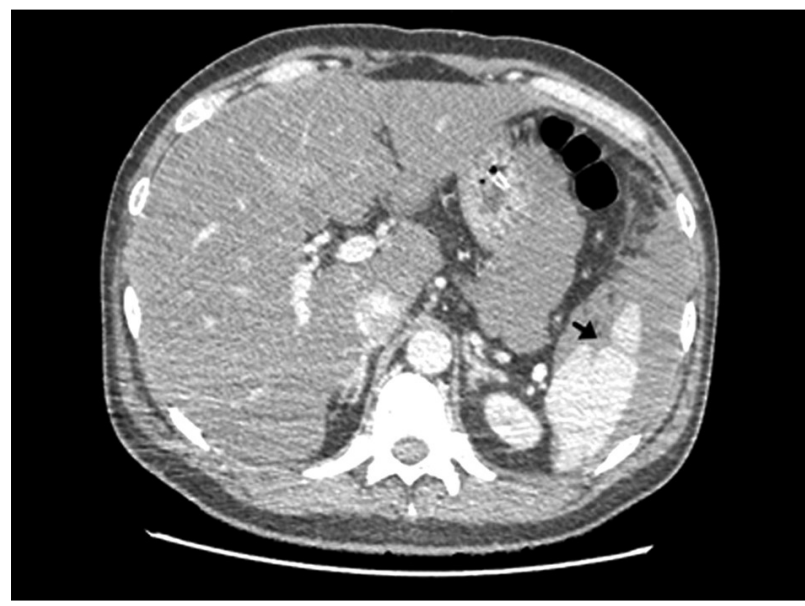

Figure 3. Suspicion of a ruptured spleen demonstrated to be a segmentate spleen (arrow)

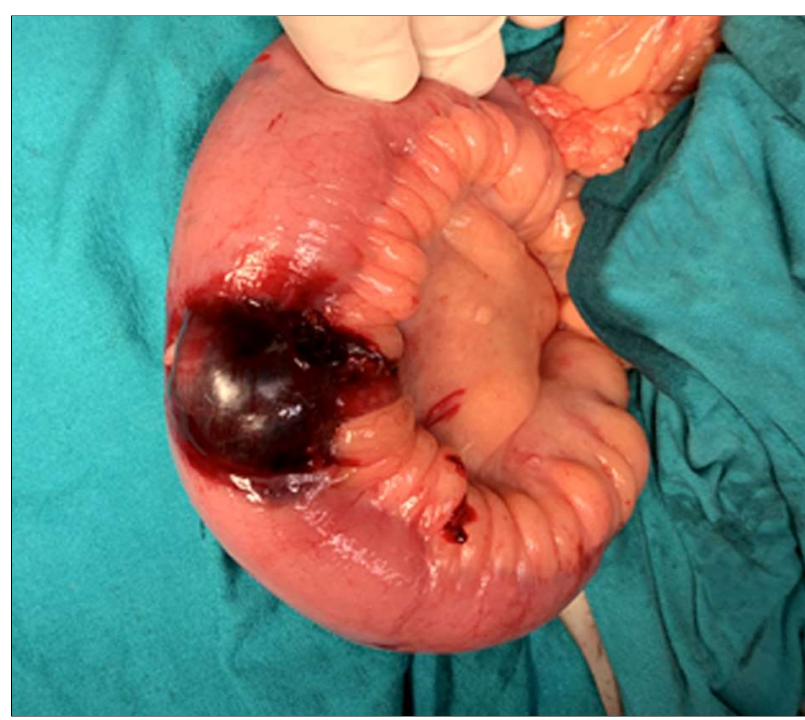

Figure 4. Ileal cavernous hemangioma 


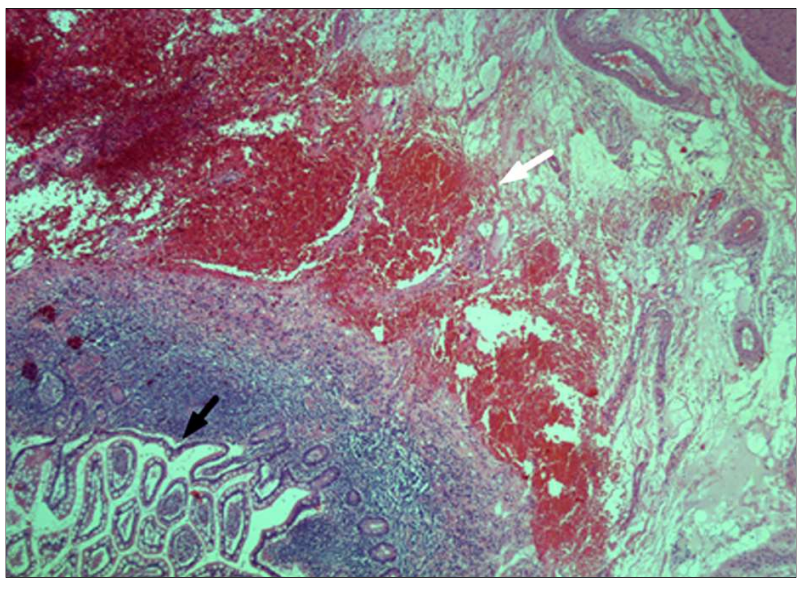

Figure 5. Pathological examination revealed cavernous hemangioma (white arrow); black arrow - bowel mucosa

(courtesy of Dr. C. Creangă and Dr. V. Enache, Department of Pathology, Bucharest Emergency Hospital)

the patient was aggravated by high blood pressure and ethanol withdrawal, both conditions being treated accordingly. The patient was discharged on the postoperative $10^{\text {th }}$ day in good condition.

\section{Discussion}

Hemangiomas of the small intestine are rare tumors found in less than $0.05 \%$ of all gastrointestinal neoplasms (6). These tumors may be solitary or occasionally multiple (in the present study only 3 cases $-12 \%$ ). We have found that these vascular tumors are more frequently found in the jejunum than the ileum (a ratio of 1.6:1). Usually, the patient presents with symptoms such gastrointestinal bleeding or/and abdominal pain. Bleeding is frequently seen in these cases, but microcytic anemia was always found in our study. In our case, the patient had a large hemoperitoneum which accounted for the error in interpretation but also had melena. In the searched literature we have not found any other case with a ruptured intestinal hemangioma and hemoperitoneum. In the present study there was a clear male prevalence (ratio of $4: 1$ ) found by less evident by a similar study done before 2016 (6). Another single-center retrospective study (Zhou et al.) found no difference in gender regarding this type of tumors (7).
Today, with the help of video capsule endoscopy and deep enteroscopy, small bowel sources of bleeding are identified in between 47$75 \%$ of obscure bleeding patients $(2,3)$. Still, in an important number of patients no clear source of bleeding is found as many of these are due to vascular tumors. In our review the rate of pretreatment diagnostic rate was still lower than our data (7 of 25 cases $-28 \%$ ). Different factors could have contributed to this low rate of detection but this, also, underline the necessity of specific methods of diagnostic that are not quite available on a large scale (i.e., enteroscopy and videocapsule). Computed tomography imaging is helpful and was used in more than one third of the cases (9 patients). CECT performed in emergency was extremely useful in our settings while, neitherenteroscopy nor videocapsule were available. Furthermore, the recent history of trauma and the presence of hemoperitoneum mislead the initial diagnostic in our case.

All the tumors in the study with one exception were benign and dominated by cavernous form of hemangioma (12 patients).

Endoscopic treatment of intestinal hemangioma, where is available might be suitable for multiple, relatively small lesions. In this review only 3 cases benefited from nonsurgical treatment, and, in another case, surgery was deemed necessary after embolization. The availability, the difficulties, and the amenability of different types of nonoperative treatment can explain the major role of surgery. In this study 22 of the cases benefited of resection (88\%). In more than half of the cases the approach was minimally invasive (12 patients - 48\%). Endoscopic treatment can stop the bleeding in some cases (mainly in small tumors), while sur-gery (laparoscopic/open) is the ultimate therapeutic method especially for larger tumors.

To our knowledge the case we have presented is the first in the literature with in-traabdominal rupture of an intestinal hemangioma mimicking traumatic hemoperitoneum.

\section{Conclusion}

Hemangioma of the small bowel while rare, 
remains elusive in terms of diagnostic which is pursued mainly for bleeding and/or anemia. Video capsule endoscopy and enteroscopy while very helpful in diagnosing this type of tumors are not available on a large scale. Surgery is the mainstay treatment for larger tumor while for smaller one new treatment methods are available. Further studies are needed to clarify the optimal management of intestinal hemangiomas.

\section{Limitations}

All studies in the review were case reports.

\section{Acknowledgements}

Dr. C. Creangă and Dr. V. Enache, Department of Pathology (Bucharest Emergency Hospital)

\section{Funding}

No funding was given.

\section{Conflict of interest}

Authors have nothing to disclose.

\section{Ethical Statement}

Informed consent was obtained from our patient presented in this study. All the other patients consented as stated in the selected papers. Furthermore, the journals cited adhere to ethical statements imposed by ICMJE.

\section{References}

1. Gunjan D, Sharma V, Rana SS, Bhasin DK. Small bowel bleeding: A comprehensive review. Gastroenterology Report. 2014;2(4):262-272.

2. Gerson LB, Fidler JL, Cave DR, Leighton JA. ACG Clinical Guideline: Diagnosis and Management of Small Bowel Bleeding. Am J Gastroenterol. 2015;110(9):1265-1287.

3. Ohmiya N. Management of obscure gastrointestinal bleeding: Comparison of guidelines between Japan and other countries. Digestive Endoscopy. 2020;32(2):204-218

4. Liberati A, Altman DG, Tetzlaff J, Mulrow C, Gotzsche PC, Ioannidis JPA, et al. The PRISMA statement for reporting systematic reviews and metaanalyses of studies that evaluate healthcare interventions: explanation and elaboration. BMJ. 2009;339:b2700.

5. Lawless ME, Lloyd KA, Swanson PE, Upton MP, Yeh MM. Lymphangioma-tous lesions of the gastrointestinal tract: a clinicopathologic Study and Comparison Between Adults and Children. Am J Clin Pathol. 2015;144(4):563-569.

6. Hu PF, Chen H, Wang XH, Wang WJ, Su N, Shi B. Small intestinal hemangioma: Endoscopic or surgical intervention? A case report and review of literature. World J Gastrointest Oncol. 2018;10(12):516.

7. Haibin Z, Lingling W, Lexing Z, Xumin B, Yingyu W, Jianfeng $Y$, et al. Clinicopathological characteristics and prognosis of gastrointestinal vascular tumours. Sci Rep. 2021;11(1):16062.
8. Jiménez B, Jiménez García V, Gómez Rodríguez B. Cavernous hemangioma of the small bowel: a case report and literature review. Cureus. 2018; 21(6): 332-333.

9. Zhang GY, Luo CJ, Zhao B, Zhan H, Long B, Guo LY, et al. Small intestinal cavernous hemangioma causing chronic hemorrhage: a case report. Nan Fang Yi Ke Da Xue Xue Bao. 2017:37(7):866-868. Chinese

10. Aoyama T, Fukumoto A, Shigita K, Asayama N, Mukai S, Nagata S. Successful endoscopic sclerotherapy using polidocanol for small bowel hemangioma. Internal Medicine. 2020;59(14):1727

11. Al-Tkrit A, Aneeb M, Mekaiel A, Alawawdeh F, Mehta A. Cavernous Hemangioma: a rare cause of massive lower gastrointestinal bleeding. Cureus. 2020;12(8):8-16.

12. Xiao NJ, Ning SB, Li T, Li BR, Sun T. Small intestinal hemolymphangioma treated with enteroscopic injection sclerotherapy: A case report and review of literature. World J Gastroenterol. 2020;26(13):1540-1545.

13. Moein Jahromi B, Tsai F. Small-bowel hemangioma: rare and hard to find. Gastrointestinal endoscopy. 2019;89(2):436-437.

14. Takase N, Fukui K, Tani T, Nishimura T, Tanaka T, Harada N, et al. Preoperative detection and localization of small bowel hemangioma: Two case reports. World J Gastroenterol. 2017;23(20):3752-3757.

15. Kano T, Fukai S, Okamoto R, Motomura Y, Lefor AK, Mizokami K. An incidentally identified $15 \mathrm{~cm}$ cavernous hemangioma of the small intestine: Case report and literature review. Int J Surg Case Rep. 2021;84:106144.

16. Silva J, Afecto E, Rodrigues A, Pinho R. Obscure gastrointestinal bleeding in the setting of blue rubber bleb nevus syndrome with extensive small bowel involvement. Revista espanola de enfermedades digestivas. 2020;112(4): 323-324.

17. Ikeoka S, Yoshizaki T, Matsuda T, Katayama N, Matsumoto M, Takagi M, et al. A rare case of pyogenic granuloma of the jejunum causing gastrointestinal bleeding. Clin J Gastroenterol. 2020;13(6):1125-1128.

18. Heo TG. Solitary jejunal cavernous hemangioma causing intermittent melena: A case report. Int J Surg Case Rep. 2021;84:106121. Epub 2021 Jun 18.

19. Grgic D, Prijic R, Romic I, Augustin G, Markoš P, Korša L, et al. A single small bowel hemangioma detected by video capsule endoscopy in a patient presenting with Iron-deficiency anemia - two case reports. Prague Med Rep. 2019:120(4):138-143

20. Duanmu J, Liang Y, Huang Z, Tan Y, Li T, Lei X. Cavernous haemangioma of the duodenum with acute massive bleeding in the ascending portion: a case report. J Int Med Res. 2021;49(9):3000605211010091.

21. Durer C, Durer S, Sharbatii M, Comba IY, Aharoni I, Majeed U. Cavernous Hemangioma of the Small Bowel: A Case Report and Literature Review. Cureus. 2018;10(8):e3113.

22. Dayan D, Raz M, Kuriansky J. Giant cavernous hemangioma of small intestine mesentery: A rare cause of recurrent acute symptomatic anemia. Isr Med Assoc J. 2019;21(6):424-425.

23. Zhang D, Glover SC, Liu W, Liu X, Lai J. Small Bowel Pyogenic Granuloma With Cytomegalovirus Infection in a Patient With Crohn's Disease (Report of a Case and Review of the Literature). In Vivo. 2019;33(1):251.

24. Ejtehadi F, Fattahi MR, Safaei A, Safarpour AR, Bananzadeh A. Practical Lessons from the Small Bowel Bleeding Lesions: A Case Report on Small Bowel Cavernous Hemangioma. Iranian Journal of Medical Sciences. 2017:42(1):108

25. Majethia H, Dhakre V, Gheewala H, Bhuta P. Ileal cavernous haemangioma in an adult presenting as a rare cause of small bowel obstruction. BMJ case reports. 2021;14(3).

26. Imaya $\mathrm{Y}$, Streutker $\mathrm{C}$, Coneys J, Marcon N. Hemangiolymphangioma of the small bowel: A rare cause of chronic anemia. Digestive and liver disease. 2018:50(11):1248.

27. Wang B, Luo Z, Zheng W, Zhang J, Liu J. Capillary hemangioma in the ileum: Obscure small-bowel bleeding in an elderly person. The Turkish Journal of Gastroenterology. 2018;29(4):520.

28. Yang SX, Zhou YH, Zhang J, Miao L, JW Zhong, WX Wang, et al. Haemorrhagic ileal haemolymphangioma: a case report and review of the literature. J Int Med Res. 2021;49(2):300060520986677. 